\title{
KESIAPAN SOSIAL KAMPUNG CIBUNUT SEBAGAI KAMPUNG KREATIF BERWAWASAN LINGKUNGAN
}

\author{
Shifa Nurul Indah Pertiwi ${ }^{1}$, Winny Astuti ${ }^{1}$, Hakimatul Mukaromah ${ }^{1}$ \\ ${ }_{1}^{1}$ Program Studi Perencanaan Wilayah dan Kota, Fakultas Teknik, Universitas Sebelas Maret
}

\begin{abstract}
Abstrak
Kota Bandung terpilih menjadi salah satu kota kreatif dari UNESCO. Kampung kreatif adalah salah satu bagian dari penerapan kota kreatif. Kampung Cibunut diresmikan menjadi kampung kreatif yang berwawasan lingkungan pada tahun 2017. Kampung Cibunut membutuhkan waktu sekitar 3 tahun untuk diresmikan sebagai kampung kreatif berwawasan lingkungan. Sedangkan, di sisi lain, beberapa kampung yang menerapkan konsep berwawasan lingkungan membutuhkan waktu minimal 5 tahun untuk diresmikan atau mendapatkan penghargaan yang berkaitan dengan berwawasan lingkungan. Dengan demikian, tujuan dari penelitian ini adalah untuk melihat tingkat kesiapan sosial dari Kampung Cibunut sebagai kampung kreatif berwawasan lingkungan. Penelitian ini menggunakan analisis skoring. Tingkat kesiapan dibagi menjadi 3, yakni tidak siap, cukup siap, dan siap. Berdasarkan hasil analisis dapat disimpulkan bahwa kondisi sosial Kampung Cibunut tergolong cukup siap dalam menjadi kampung kreatif berwawasan lingkungan. Dari hasil analisis dapat dilihat bahwa tingat kemampuan masyarakat dalam hal berwawasan lingkungan tergolong tinggi, selain itu kelembagaan di Kampung Cibunut juga cukup baik dalam mendukung kampung kreatif berwawasan lingkungan.
\end{abstract}

Kata Kunci : berwawasan lingkungan; kampung kreatif; kesiapan; kota kreatif

\begin{abstract}
Bandung was selected as one of the creative cities by UNESCO. Creative village is part of the creative city concept. Kampung Cibunut was selected as a creative village that environmentally friendly in 2017. The village only took about 3 years to became a creative village that environmentally friendly. Meanwhile, , for several other villages need minimum 5 years to formalized or get an award related to environmental friendliness. The purposes of this research is to identify the level of social readiness of Kampung Cibunut as a creative village that environmentally friendly. This research applies scoring analysis. The scales of readiness divided into 3 categories, not ready, quite ready, and ready. The results reveal that social condition of Kampung Cibunut is classified as ready to became creative village that environmentally friendly. The analysis on the ability of the community to achieve environmental friendliness is high. Moreover, the institutions to support the village program to achieve the status of environmental friendly village is classified as quite good
\end{abstract}

Keywords : creative city; creative village; environmental friendliness; readiness

\section{PENDAHULUAN}

Pada tahun 2009, UNESCO membuat suatu jaringan kota kreatif yang menghubungkan kota-kota kreatif. Jaringan kota kreatif tersebut digunakan untuk berbagi pengalaman, ide, dan gagasan. Kota-kota kreatif ini memiliki 7 sektor fokus, yakni literatur, film, musik, kerajinan dan folk art, desain, media arts, dan gastronomi. Pada tahun 2015, UNESCO memilih Kota Bandung menjadi salah satu Kota Kreatif Dunia bersama 47 kota lainnya. Kota Bandung merupakan kota kedua di Indonesia, setelah Pekalongan, yang dipilih menjadi kota kreatif oleh UNESCO. Kota Bandung termasuk dalam sektor Kota Kreatif dari segi desain. Salah satu alasan Kota Bandung dipilih menjadi Kota Kreatif adalah terdapat komunitas-komunitas kreatif yang menjadi penggerak roda ekonomi Kota Bandung dan juga terdapat industri kreatif yang mampu menyerap tenaga kerja (Martini, 2016).

Landry berpendapat bahwa aspek penting untuk membentuk kota kreatif itu ada 3, yakni ekonomi kreatif, pengembangan individu atau komunitas kreatif, dan adanya lingkungan kreatif yang mampu mendukung kreativitas (Landry, 2006). Salah satu cara penciptaan ruang kreatif adalah dengan kampung kreatif. Kampung kreatif ini merupakan gagasan dari komunitas agar ruang kreatif tersedia, sehingga mampu untuk meningkatkan perekonomian. 
Pada tanggal 27 November 2017, Walikota Bandung meresmikan salah satu Kampung Kreatif yang berlokasi di daerah Cibunut, Kelurahan Kebon Pisang, Kecamatan Sumur Bandung, Kota Bandung sebagai kampung kreatif berwawasan lingkungan (Mulyadi, 2017). Kampung Kreatif Cibunut yang berada di Jalan Sunda ini awalnya termasuk ke dalam kawasan kumuh yang berada di dekat sungai. Dengan bantuan dari berbagai pihak, mulai dari Karang Taruna, Ikatan Alumni ITB, Ikatan Alumni SMAN 3 Bandung, hingga CSR dari Azkonobel Decorative Paints Indonesia, Kampung Cibunut mampu menghilangkan status permukiman kumuhnya. Saat diresmikan, kawasan kumuh ini telah berubah menjadi kampung warna-warni yang berhiaskan mural di setiap dindingnya. Selain itu, terdapat pula pengelolaan sampah yang berupa bank sampah dan biodigester. Pengelolaan sampah dengan cara pemilahan sampah organik dan anorganik ini dimulai masyarakat dengan Gerakan Pungut Sampah (GPS). Gerakan Pungut Sampah dicetuskan oleh pemuda di Kampung Cibunut yang tergabung dalam komunitas Kegiatan Swadaya Masyarakat Orang Hebat Sadar Lingkungan (KSM Oh Darling).

Berdasarkan hasil eksplorasi, kampung dengan prinsip berwawasan lingkungan dan ramah lingkungan membutuhkan waktu yang terbilang lama dalam penerapannya. Beberapa kampung sejenis antara lain Kampung Glintung Go Green di Kota Malang, Desa Larangan Sidoarjo, Desa Sukunan di Jogjakarta, dan Desa Jambangan di Surabaya. Keempat kampung dengan penerapan wawasan lingkungan membutuhkan waktu di atas 5 tahun untuk diresmikan atau mendapat penghargaan. Hal tersebut juga disebutkan dalam teori, bahwa mengubah perilaku masyarakat memang membutuhkan waktu yang relatif lebih lama (Archie, Clark, \& Braus, 2017). Kegiatan kampung berwawasan lingkungan di Kampung Cibunut dimulai pada tahun 2015 dan diresmikan sebagai kampung kreatif berwawasan lingkungan pada tahun 2017. Jika dilihat dari keempat kampung sebelumnya, proses penerapan wawasan lingkungan di Kampung Cibunut hingga diresmikan menjadi kampung kreatif berwawasan lingkungan relatif singkat. Di sisi lain, Pemerintah Kota Bandung memiliki target membentuk 30 kampung kreatif di Kota Bandung hingga tahun 2018 (Saqina, 2013). Kampung kreatif berwawasan lingkungan memiliki beberapa komponen besar, yaitu berkaitan dengan ekonomi, sosial, dan fisik, penelitian ini akan membahas mengenai kesiapan Kampung Cibunut sebagai kampung kreatif berwawasan lingkungan dari segi sosial. Oleh karena itu, penelitian ini akan membahas mengenai kesiapan Kampung Cibunut sebagai kampung kreatif berwawasan lingkungan. Untuk melihat apakah Kampung Cibunut sudah benar-benar siap menjadi kampung kreatif berwawasan lingkungan atau hanya sebagai pemenuh target 30 kampung kreatif oleh Pemerintah Kota Bandung di tahun 2018 (Saqina, 2013).

\section{KAJIAN PUSTAKA}

\subsection{KESIAPAN}

Berdasarkan Kamus Besar Bahasa Indonesia, siap merupakan kata kerja yang memiliki arti sudah disediakan atau sudah sedia. Sedangkan kesiapan, merupakan kata turunan dari siap, yang memiliki arti keadaan siap, sudah hampir $100 \%$ rampung. Kesiapan merupakan kondisi sedia dalam mengahadapi atau merespon suatu situasi. Dasar dari kesiapan adalah (www.businessdictionary.com) :

a Adanya rencana yang menyeluruh

Ketersediaan rencana yang mencakup keseluruhan dari situasi.

b Kecukupan dan pelatihan Sumber Daya Manusia

Kata cukup memiliki arti dapat memenuhi kebutuhan dan tidak kurang. Kebutuhan yang dimaksud adalah kebutuhan akan sumber daya manusia.

c Ketersediaan fisik yang mendukung (sistem, infrastruktur)

Mendukung adalah membantu atau menunjang. Ketersediaan fisik yang mendukung ialah adanya sistem dan infrastruktur yang dapat menunjang suatu situasi.

Kesiapan dapat dilihat dari adanya rencana menyeluruh, kecukupan dan pelatihan SDM, serta ketersediaan fisik yang mendukung.

\subsection{KAMPUNG KREATIF}

Kampung kreatif sendiri merupakan perwujudan dari lingkungan atau ruang kreatif. Adanya kampung kreatif didasari oleh gagasan komunitas agar suatu kota dapat memiliki banyak ruang kreatif (Heru, 2015). Secara tidak langsung, dapat dikatakan bahwa kampung kreatif merupakan bagian dari kota kreatif. Komponen dari kota kreatif dapat diterapkan dalam kampung kreatif namun dalam skala yang lebih kecil. 
Menurut pendapat Landry, faktor-faktor sosial yang mempengaruhi dalam penciptaan pemikiran kreatif meliputi kualitas personal, keinginan dan kepemimpinan, keberagaman bakat, budaya berorganisasi, serta jaringan kerjasama (Landry, 2008).

a Kualitas personal berkaitan dengan ketersediaan individu kreatif dengan pemikiran terbuka. Individu kreatif diperlukan sebagai pengaruh, sehingga semua masyarakat tergerak, memiliki pikiran yang terbuka, dan lebih berani.

b Suatu pemimpin diperlukan dalam melihat apa yang ingin dituju dan bagaimana mencapai tujuan. Di sisi lain, keinginan dari masyarakat untuk berubah juga diperlukan.

c Landry (2008) berpendapat bahwa keberagaman bakat ini datang dari para pendatang. Hal ini dikarenakan para pendatang dinilai lebih cepat dalam melihat potensi dan masalah di kawasan barunya. Namun, keberadaan penduduk lokal juga tetap diperlukan untuk mempertahankan lokalitas dan kreativitas. Keragaman ini berpotensi dalam pembentukan inovasi dan pertukaran gagasan.

d Budaya berorganisasi dinilai mampu mendorong solusi kreatif dan secara tidak langsung dapat memunculkan sebuah ruang yang inovatif. Budaya berorganisasi ini bersifat life long learner, di mana ada upaya dalam pengembangan kemampuan dan kapasitas masyarakat.

e Jaringan kerja sama meliputi pemerintah, swasta, dan sukarelawan. Jaringan kerja sama berkaitan dengan inovasi dan kreativitas. Semakin banyak jairngan kerja sama, kesempatan untuk belajar dan berinovasi juga semakin besar.

\subsection{BERWAWASAN LINGKUNGAN}

Berwawasan lingkungan merupakan upaya sadar dan terencana dalam pengelolaan sumber daya dengan bijak dalam pembangunan berkelanjutan guna meningkatkan kualitas hidup manusia (Ervianto, 2016). Di Indonesia sendiri, dokumen mengenai isu wawasan lingkungan disusun oleh Kementerian Pekerjaan Umum, yakni Program Pembangunan Kota Hijau (P2KH). Berdasarkan P2KH, komponen berwawasan lingkungan yang berkaitan dengan skala kampung dapat dilihat pada Tabel 1.

Tabel 1. Sintesis Berwawasan Lingkungan

Kementerian PUPR, 2017 Sintesis

Perencanaan dan perancangan kota yang ramah lingkungan

(membahas mengenai perencanaan dan perancangan dalam skala yang luas)

Ketersediaan ruang terbuka hijau

Ketersediaan ruang terbuka hijau

Konsumsi energi dan efisiensi

Konsumsi energi dan efisiensi

Pengelolaan air yang efektif

Pengelolaan air yang efektif

Pengelolaan sampah ramah lingkungan

Pengelolaan sampah ramah lingkungan

Bangunan hijau

(membahas mengenai bangunan gedung ramah lingkungan, sehingga tidak sesuai untuk kawasan permukiman)

Penerapan transportasi berkelanjutan Penerapan transportasi berkelanjutan

Penerapan peran masyarakat sebagai komunitas hijau Kelembagaan

\subsection{KESIAPAN ASPEK SOSIAL PADA KAMPUNG KREATIF BERWAWASAN LINGKUNGAN}

Komponen ini didapatkan dari hasil persilangan kesiapan, kampung kreatif, dan kampung berwawasan lingkungan. Hasil dari persilangan tersebut mendapatkan 2 variabel, yakni mengenai keberagaman bakat berwawasan lingkungan dan kelembagaan. Variabel dan subvariabel tersebut adalah :

- Variabel keberagaman bakat berwawasan lingkungan memiliki 4 subvariabel, yaitu kemampuan masyarakat dalam pengelolaan kualitas RTH, kemampuan masyarakat dalam penggunaan energi secara efisien, kemampuan masyarakat dalam pengelolaan air berwawasan lingkungan, dan kemampuan masyarakat dalam pengelolaan sampah/limbah berwawasan lingkungan.

- Variabel kelembagaan memiliki 3 subvariabel yang berkaitan dengan kegiatan pengembangan kemampuan masyarakat, kepemimpinan, serta adanya kerja sama. 


\section{METODE PENELITIAN}

Pendekatan dalam penelitian ini bersifat deduktif, penelitian ini, di mana pendekatan dilakukan dengan menentukan variabel dari teori-teori yang telah tersedia, kemudian dilakukan penarikan kesimpulan. Metode survei yang digunakan adalah observasi dan wawancara kepada Ketua Komunitas Orang Hebat Sadar Lingkungan.

\subsection{LOKASI PENELITIAN}

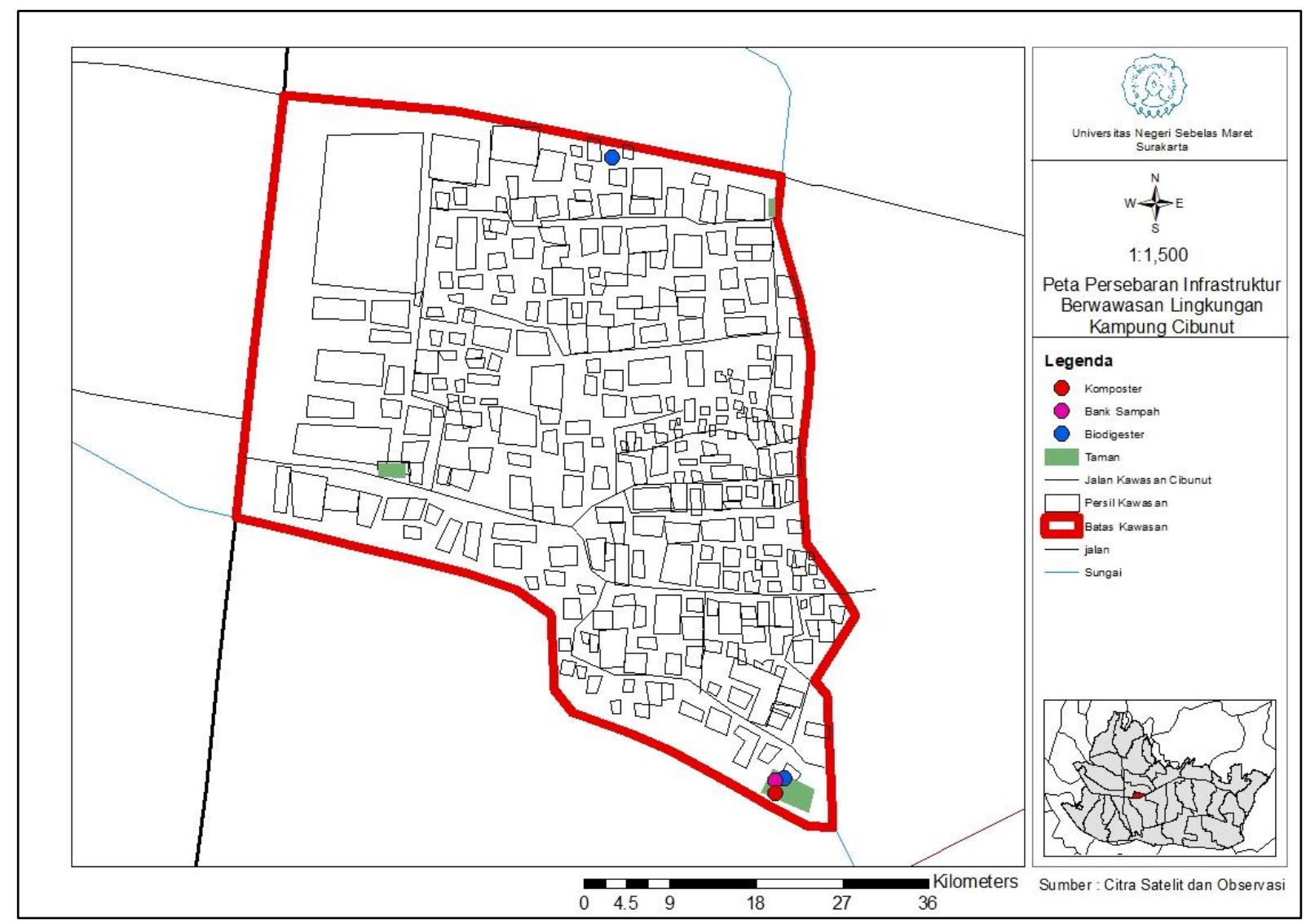

Gambar 1. Peta Persebaran Infrastruktur Berwawasan Lingkungan Kampung Cibunut

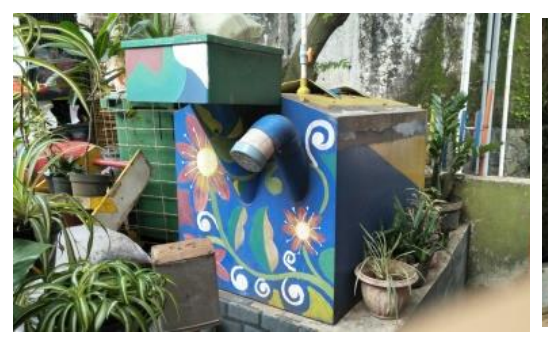

Gambar 2. Biodigester

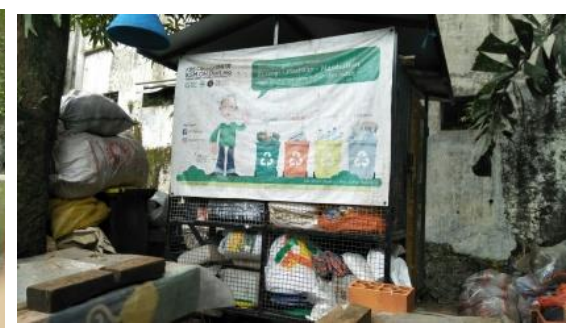

Gambar 3. Bank Sampah

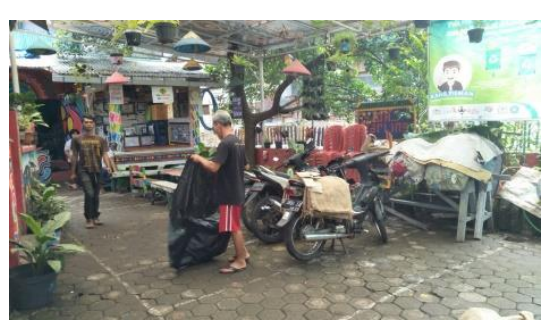

Gambar 4. Taman

Kelurahan Kebon Pisang merupakan salah satu kelurahan yang berada di Kecamatan Sumur Bandung, Kota Bandung. Kelurahan ini memiliki luas sekitar $0,65 \mathrm{~km}^{2}$ dan terdiri dari 12 RW serta 85 RT (BPS, 2017). Kampung Cibunut atau RW 07 merupakan salah satu RW yang berlokasi di Kelurahan Kebon Pisang dan terdiri dari 9 RT. Kampung Cibunut ini memiliki luas sekitar $31.478 \mathrm{~m}^{2}$ dan dihuni oleh $550 \mathrm{KK}$ atau sekitar 1600 jiwa.

Pada tanggal 27 November 2017, Walikota Bandung meresmikan salah satu Kampung Kreatif yang berlokasi di daerah Cibunut, Kelurahan Kebon Pisang, Kecamatan Sumur Bandung, Kota Bandung sebagai kampung kreatif berwawasan lingkungan (Mulyadi, 2017). Kampung Cibunut dikenal karena pengolahan sampahnya yang dinilai baik. Pengolahan sampah di Kampung Cibunut meliputi, pemilahan sampah dari sumber, bank sampah, komposter, dan biodigester (lihat Gambar 1). Selain itu, terdapat pula kegiatan ramah lingkungan seperti kegiatan earth hour yang 
dibarengi dengan jurit malam setiap peringatan 17 Agustus, adanya biopori, penggunaan keranjang atau 'besek' untuk membungkus hasil kurban, dan pemanfaatan lahan-lahan kecil guna ruang terbuka hijau (lihat Gambar 2 dan 3).

Kegiatan berwawasan lingkungan ini bekerja sama dengan berbagai pihak, seperti DLHK, GSSI, dan beberapa sukarelawan lain, yaitu Jurnal Risa, Ikatan Alumni ITB, Ikatan Alumni SMAN 3 Bandung, dan Komunitas Mural Bandung. Selain keterlibatan pihak luar, keterlibatan masyarakat RW 7 juga sangat berpengaruh dalam merealisasikan kampung kreatif berwawasan lingkungan. Keterlibatan masyarakat dapat dilihat dari adanya kemauan masyarakat untuk memilah sampah dari sumber, keterlibatan dalam pembuatan lubang biopori, kesadaran masyarakat dalam mematikan barang elektronik yang tidak digunakan, ikut memadamkan lampu saat kegiatan earth hour atau jurit malam, hingga turut serta dalam membersihkan serta merawat taman (lihat Gambar 4). Seluruh kegiatan berwawasan lingkungan ini bantu juga oleh organisasi di dalam kawasan, yaitu Karang Taruna dan Komunitas Orang Hebat Sadar Lingkungan. Terlebih ketua RW 7 juga mendukung dan berpartisipasi dalam kegitan berwawasan lingkungan tersebut. Karang Taruna berperan dalam pembuatan mural, kegiatan jurit malam, dan pemasaran dalam bentuk digital. Sedangkan Komunitas OHDarling lebih berperan dalam kegiatan pengelolaan sampah, pengelolaan air, dan merawat taman yang berada di Kampung Cibunut.

\subsection{OPERASIONAL VARIABEL}

\subsubsection{VARIABEL KEBERAGAMAN BAKAT BERWAWASAN LINGKUNGAN}

Variabel keberagaman bakat berwawasan lingkungan memiliki 4 subvariabel, yakni kemampuan masyarakat dalam pengelolaan kualitas RTH, kemampuan masyarakat dalam penggunaan energi secara efisien, kemampuan masyarakat dalam pengelolaan air berwawasan lingkungan, dan kemampuan masyarakat dalam pengelolaan sampah/limbah. Variabel keberagaman masyarakat menggunakan data dari hasil kuesioner. Indikator dari variabel ini mengunakan skor 1, 2, dan 3 untuk melihat kesesuaian berdasarkan teori keragaman bakat berwawasan lingkungan (lihat Tabel 2). Semakin tinggi skor, mewakili kesiapan dari komponen berdasarkan teori atau dapat dikatakan sebagai parameter kesiapannya.

Tabel 2. Indikator Variabel Keberagaman Bakat Berwawasan Lingkungan

\begin{tabular}{|c|c|c|c|c|}
\hline \multirow{2}{*}{ Subvariabel } & \multirow{2}{*}{ Parameter } & \multicolumn{3}{|c|}{ Indikator } \\
\hline & & Tidak Siap (1) & Cukup Siap (2) & Siap (3) \\
\hline $\begin{array}{l}\text { Kemampuan masyarakat } \\
\text { dalam pengelolaan kualitas } \\
\text { RTH } \\
\text { Kemampuan masyarakat } \\
\text { dalam penggunaan energi } \\
\text { secara efisien } \\
\text { Kemampuan masyarakat } \\
\text { dalam pengelolaan air } \\
\text { berwawasan lingkungan } \\
\text { Kemampuan masyarakat } \\
\text { dalam pengelolaan } \\
\text { sampah/limbah berwawasan } \\
\text { lingkungan }\end{array}$ & $\begin{array}{l}\text { Masyarakat mampu berperan } \\
\text { dalam pengelolaan kualitas } \\
\text { RTH } \\
\text { Masyarakat mampu berperan } \\
\text { dalam penggunaan energi } \\
\text { secara efisien } \\
\text { Masyarakat mampu berperan } \\
\text { dalam pengelolaan air } \\
\text { berwawasan lingkungan } \\
\text { Masyarakat mampu berperan } \\
\text { dalam pengelolaan sampah/ } \\
\text { limbah berwawasan lingkungan }\end{array}$ & $\begin{array}{c}\text { Tidak ada } \\
\text { masyarakat yang } \\
\text { mampu }\end{array}$ & $\begin{array}{c}1-50 \% \\
\text { masyarakat } \\
\text { mampu }\end{array}$ & $\begin{array}{c}>50 \% \\
\text { masyarakat } \\
\text { mampu }\end{array}$ \\
\hline
\end{tabular}

\subsubsection{VARIABEL KELEMBAGAAN}

Variabel kelembagaan memiliki 3 subvariabel, yakni berkenaan dengan kegiatan pengembangan kemampuan masyarakat, kepemimpinan, dan kerja sama. Setiap subvariabel memiliki penggolongan skor yang sama, yakni 1, 2, dan 3 berdasarkan parameter yang telah ditentukan (lihat Tabel 3). Sehingga, skor yang tinggi dapat diartikan sebagai semakin siapnya peran dari setiap subvariabel dalam kampung kreatif berwawasan lingkungan. 
Tabel 3. Indikator Variabel Kelembagaan

\begin{tabular}{|c|c|c|c|c|}
\hline \multirow{2}{*}{ Subvariabel } & \multirow{2}{*}{ Parameter } & \multicolumn{3}{|c|}{ Indikator } \\
\hline & & Tidak Siap (1) & Cukup Siap (2) & Siap (3) \\
\hline $\begin{array}{l}\text { Kegiatan } \\
\text { pengembangan } \\
\text { kemampuan masyarakat }\end{array}$ & $\begin{array}{l}\text { Rencana rutin kegiatan training/sosialisasi } \\
\text { pengelolaan kualitas RTH } \\
\text { Rencana rutin training/sosialisasi penggunaan } \\
\text { energi secara efisien } \\
\text { Rencana rutin training/sosialisasi pengelolaan } \\
\text { air berwawasan lingkungan } \\
\text { Rencana rutin training/sosialisasi pengelolaan } \\
\text { sampah/limbah berwawasan lingkungan }\end{array}$ & $\begin{array}{l}\text { Tidak ada } \\
\text { trainingl } \\
\text { sosialisasi }\end{array}$ & $\begin{array}{l}\text { Ada trainingl } \\
\text { sosialisasi dan } \\
\text { tidak rutin }\end{array}$ & $\begin{array}{l}\text { Ada trainingl } \\
\text { sosialisasi rutin }\end{array}$ \\
\hline Kepemimpinan & $\begin{array}{l}\text { Rencana pemimpin dalam pengelolaan kualitas } \\
\text { RTH } \\
\text { Rencana pemimpin dalam penggunaan energi } \\
\text { secara efisien } \\
\text { Rencana pemimpin dalam pengelolaan air } \\
\text { berwawasan lingkungan } \\
\text { Rencana pemimpin dalam pengelolaan sampah } \\
\text { berwawasan lingkungan }\end{array}$ & $\begin{array}{l}\text { Tidak } \\
\text { rencana }\end{array}$ & $\begin{array}{l}\text { Terdapat } \\
\text { rencana namun } \\
\text { belum jelas } \\
\text { pelaksanaannya }\end{array}$ & $\begin{array}{l}\text { Terdapat } \\
\text { rencana yang } \\
\text { pelaksanaannya } \\
\text { jelas }\end{array}$ \\
\hline Kerja sama & $\begin{array}{l}\text { Adanya kerja sama dalam pemenuhan dan } \\
\text { pengelolaan RTH (pemerintah, swasta, } \\
\text { sukarelawan) } \\
\text { Adanya kerja sama dalam penggunaan energi } \\
\text { berwawasan lingkungan (pemerintah, swasta, } \\
\text { sukarelawan) } \\
\text { Adanya kerja sama dalam pengelolaan air } \\
\text { berwawasan lingkungan (pemerintah, swasta, } \\
\text { sukarelawan) } \\
\text { Adanya kerja sama dalam pengelolaan } \\
\text { sampah/limbah berwawasan lingkungan } \\
\text { (pemerintah, swasta, sukarelawan) }\end{array}$ & $\begin{array}{l}\text { Tidak ada kerja } \\
\text { sama }\end{array}$ & $\begin{array}{l}\text { Kerja sama 1-2 } \\
\text { stakeholder }\end{array}$ & $\begin{array}{ll}\text { Kerjasama } & >2 \\
\text { stakeholder } & \end{array}$ \\
\hline
\end{tabular}

\subsection{POPULASI DAN SAMPEL}

Data-data untuk menjawab setiap variabel didapatkan dari hasil wawancara, dan kuesioner. Dimana wawancara dilakukan kepada ketua Komunitas Orang Hebat Sadar Lingkungan dan kuesioner dilakukan dengan responden masyarakat. Wawancara dilakukan untuk mendapatkan data berkaitan dengan kelembagaan, yakni mengenai kegiatan pengembangan kemampuan masyarakat, kepemimpinan dan kerja sama.

Kuesioner ditujukan kepada masyarakat untuk mengetahui kemampuan masyarakat dalam hal berwawasan lingkungan. Penentuan sampel ini menggunakan rumus dari Slovin, yakni (Indrawan \& Yaniawati, 2014) :

$$
\mathrm{n}=\mathrm{N} / \mathrm{N}(\mathrm{d})^{2}+1
$$

$$
\text { dimana, } \begin{aligned}
n & =\text { sampel } \\
N & =\text { populasi } \\
d & =\text { nilai presisi }
\end{aligned}
$$

Jumlah penduduk di Kampung Cibunut sekitar 1600 jiwa dengan jumlah KK adalah 550. Kegiatan berwawasan lingkungan di Kampung Cibunut mayoritas dilakukan perrumah, oleh karenanya digunakan populasi berupa jumlah KK, sehingga :

$$
\mathrm{n}=550 / 550(0,1)^{2}+1=84.6(\sim 85)
$$

Jadi, jumlah responden untuk kuesioner yang berkaitan dengan data kemampuan masyarakat adalah minimal 85 responden. 


\subsection{TEKNIK ANALISIS}

\subsubsection{ANALISIS SKORING}

Analisis skoring dilakukan untuk mengidentifikasi setiap komponen yang ada dalam kawasan penelitian. Perhitungan skor dilakukan untuk setiap subvariabel, kemudian skor tersebut dijumlahkan dan dirata-ratakan, sehingga didapatkan skor untuk setiap variabel.

Kategori tingkat kesiapan dibagi menjadi 3 dengan pembagian menggunakan rumus berikut :

Banyak kelas $=1+3,33$ logn

Dimana, $\mathrm{n}$ adalah banyak kelas dalam penelitian

Banyak kelas $=1+3,33 \log 3=2,59$ dibulatkan ke atas menjadi 3 .

$$
\begin{aligned}
& \text { Interval }=\frac{\text { nilai maks }- \text { nilai } \min }{3} \\
& \text { Interval }=\frac{3-1}{3}=0.7
\end{aligned}
$$

Jadi, nilai kesiapan pada penelitian ini adalah :

- Jika hasil rata-rata skor adalah 1-1.7, dapat diartikan bahwa Kampung Cibunut dinilai tidak siap dalam penerapan kampung kreatif berwawasan lingkungan secara sosial.

- Jika hasil rata-rata skor adalah 1.8-2.5 dapat diartikan bahwa Kampung Cibunut dinilai cukup siap dalam penerapan kampung kreatif berwawasan lingkungan secara sosial.

- Jika hasil rata-rata skor adalah 2.5-3, dapat diartikan bahwa Kampung Cibunut dinilai siap dalam penerapan kampung kreatif berwawasan lingkungan secara sosial.

\section{HASIL DAN PEMBAHASAN}

\subsection{TINGKAT KESIAPAN SOSIAL}

\subsubsection{TINGKAT KESIAPAN ASPEK KEBERAGAMAN BAKAT BERWAWASAN LINGKUNGAN}

Indikator dari variabel ini mengunakan skor 1, 2, dan 3 untuk melihat kesesuaian berdasarkan teori keragaman bakat berwawasan lingkungan. Semakin tinggi skor, mewakili kesiapan dari komponen berdasarkan teori atau dapat dikatakan sebagai parameter kesiapannya. Jika tidak terdapat masyarkat yang mampu maka mendapatkan skor 1 , jika terdapat kurang dari 50\% masyarakat yang mampu maka tergolong dalam indikator cukup siap atau skor 2, dan mendapatkan skor 3 atau tergolong siap jika terdapat lebih dari masyarakat yang mampu dalam melakukan kegiatan berwawasan lingkungan.

Tabel 4. Hasil Kuesioner Keberagaman Bakat Berwawasan Lingkungan

\begin{tabular}{lllcc}
\hline \multicolumn{1}{c}{ Aspek } & \multicolumn{1}{c}{ Komponen } & \multicolumn{1}{c}{ Indikator } & $\begin{array}{c}\text { Jumlah } \\
\text { Masyarakat }\end{array}$ & Total \\
\hline Pengelolaan RTH & Membersihkan taman & Tidak & 12 & \\
& & Ya, tapi tidak rutin & 46 & 85 \\
& Pemeliharaan tanaman & Ya, secara rutin & 27 & \\
& & Tidak & 14 & \\
& & Ya, tapi tidak rutin & 45 & 85 \\
\hline Efisiensi energi & Mematikan barang elektronik yang tidak & Tidak & 26 & \\
& digunakan & Jarang & 0 & \\
& & Selalu & 1 & 85 \\
& Partisipasi dalam earth hour & Tidak & 84 & \\
& & Jarang & 2 & \\
& & Selalu & 4 & 85 \\
\hline
\end{tabular}




\begin{tabular}{|c|c|c|c|c|}
\hline Aspek & Komponen & Indikator & $\begin{array}{c}\text { Jumlah } \\
\text { Masyarakat }\end{array}$ & Total \\
\hline \multirow[t]{6}{*}{ Pengelolaan air } & \multirow[t]{3}{*}{ Pembuatan lubang biopori } & Tidak & 46 & \\
\hline & & $\begin{array}{l}\text { Ya, mengikuti sebagian } \\
\text { proses }\end{array}$ & 0 & 85 \\
\hline & & $\begin{array}{l}\text { Ya, mengikuti seuruh } \\
\text { proses }\end{array}$ & 39 & \\
\hline & \multirow{3}{*}{$\begin{array}{l}\text { Memasukan sampah organik ke dalam } \\
\text { lubang biopori }\end{array}$} & Tidak & 19 & \\
\hline & & Ya, tapi tidak rutin & 23 & 85 \\
\hline & & Ya, secara rutin & 43 & \\
\hline \multirow{9}{*}{$\begin{array}{l}\text { Pengelolaan sampah/ } \\
\text { limbah }\end{array}$} & \multirow[t]{3}{*}{ Melakukan pemilahan sampah } & Tidak & 0 & \\
\hline & & Jarang & 5 & 85 \\
\hline & & Selalu & 80 & \\
\hline & \multirow{3}{*}{$\begin{array}{l}\text { Memberikan sampah anorganik ke bank } \\
\text { sampah }\end{array}$} & Tidak & 1 & \\
\hline & & Jarang & 24 & 85 \\
\hline & & Selalu & 60 & \\
\hline & \multirow{3}{*}{$\begin{array}{l}\text { Memberikan sampah organik untuk } \\
\text { proses komposting }\end{array}$} & Tidak & 1 & \\
\hline & & Jarang & 23 & 85 \\
\hline & & Selalu & 61 & \\
\hline
\end{tabular}

Dari data kuesioner di atas (lihat Tabel 4) didapatkan bahwa persentase masyarakat yang mampu dalam pengelolaan RTH adalah $71.9 \%$, persentase dalam efisiensi energi adalah $98.2 \%$, pengelolaan air berwawasan lingkungan adalah $70.4 \%$, dan pengelolaan sampah/limbah berwawasan lingkungan adalah $92.7 \%$. Oleh karenanya, skor untuk keempat komponen tersebut ada 3 karena terdapat lebih dari $50 \%$ masyarakat yang memiliki kemampuan dalam keempat kegiatan berwawasan lingkungan tersebut.

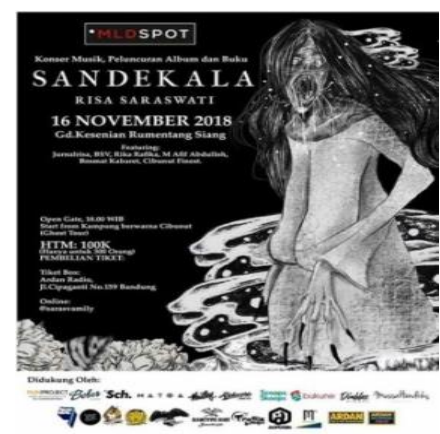

Gambar 5. Poster Jurit Malam

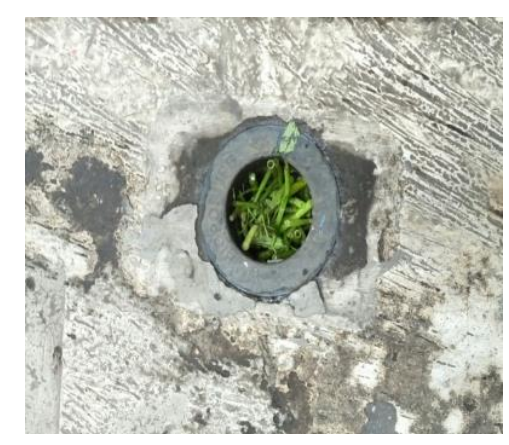

Gambar 6. Biopori

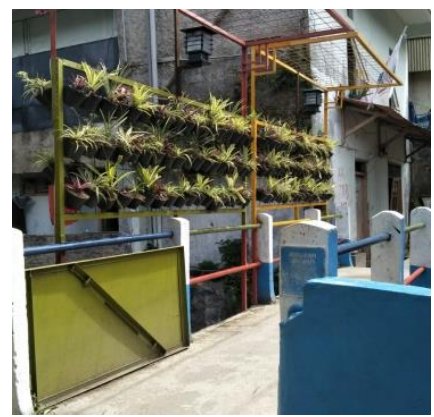

Gambar 7. Vertical Garden

Kemampuan masyarakat dalam keempat komponen di atas tergolong tinggi atau skor 3, sehingga untuk tingkat keragaman bakat berwawasan yang berada di Kampung Cibunut termasuk dalam indikator siap. Hal tersebut dikarenakan beberapa hal, mulai dari pengelolaan RTH hingga pengelolaan sampah berwawasan lingkungan. Dalam pengelolaan RTH, masyarakat bergerak atas inisiatif sendiri. Terlebih, masyarakat memiliki rasa bangga tersendiri saat mereka menyumbang, baik dalam bentuk dana maupun tenaga, untuk Kampung Cibunut. Sedangkan untuk efisiensi energi, partisipasi masyarakat dalam memadamkan lampu untuk mendukung kegitan jurit malam juga sangat tinggi (lihat Gambar 5). Rumah-rumah yang tidak berpartisipasi dalam pemadaman lampu mayoritas dihuni oleh masyarakat berusia lanjut dengan alasan keamanan. Selain itu, kemampuan masyarakat dalam efisiensi energi ini didukung oleh kesadaran masyarakat yang tinggi dalam mematikan alat elektronik yang tidak digunakan. Untuk pengelolaan air, pembuatan lubang biopori memang dilakukan oleh masyarakat. DLHK berperan dalam pengadaan bor untuk biopori dan masyarakat berperan dalam pembuatan dan bahan-bahan lain yang dibutuhkan, seperti paralon dan tutup untuk biopori (lihat Gambar 6 dan 7). Meski tinggi, persentase untuk pengelolaan air adalah yang paling rendah di antara seluruh komponen. Hal ini karena tidak semua rumah memiliki lubang biopori, sehingga sampah organik langsung disalurkan ke petugas kebersihan dan tempat komposting. Kampung Cibunut memang terkenal dengan pengelolaan sampahnya, oleh 
karenanya dapat dilihat bahwa masyarakat dapat memilah sampahnya sendiri dan mendistribusikan sampah anorganiknya ke bank sampah serta sampah organik ke lubang biopori atau tempat komposting.

Adanya keberagaman bakat berpotensi dalam pembentukan inovasi dan pertukaran gagasan guna menciptakan pemikiran kreatif (Landry, 2008). Secara luas, Landry berpendapat bahwa keberagaman bakat ini terjadi karena adanya pendatang dan penduduk lokal. Sedangkan, meninjau dari komponen berwawasan lingkungan pada Program Pebangunan Kota Hijau oleh Kementerian PUPR, atribut yang melibatkan masyarakat antara lain, RTH, konsumsi energi dan efisiensi, pengelolaan air yang efektif, dan pengelolaan sampah ramah lingkungan (KemenPUPR, 2017). Sehingga, keberagaman bakat dalam kampung kreatif berwawasan lingkungan berkaitan dengan keempat atribut tersebut. Berdasarkan hasil analisis skoring, dapat dilihat bahwa lebih dari 50\% masyarakat mampu melakukan pengelolaan RTH, efisiensi energi, pengelolaan air, dan pengelolaan sampah/limbah. Sehingga, seperti yang dikatakan Landry mengenai keberagaman bakat, di Kampung Cibunut terdapat keberagaman bakat dalam hal berwawasan lingkungan. Adanya keberagaman bakat di Kampung Cibunut berpotensi dalam penciptaan pemikiran kreatif yang kemudian akan mendukung terciptanya kampung kreatif.

\subsubsection{KELEMBAGAAN}

Kelembagaan ini meliputi 3 komponen yaitu, kegiatan pengembangan masyarakat, kepemimpinan, dan kerja sama. Untuk komponen kegiatan pengembangan masyarakat, Kampung Cibunut memiliki beberapa training/sosialisasi guna pengembangan kemampuan masyarakat, yaitu :

- Training/Sosialisasi Pengelolaan RTH

Pengelolaan RTH dilakukan berdasarkan inisiatif dari masyarakat yang bertempat tinggal di sekitar RTH, mulai dari membersihkan, mengecat, memperbaiki taman jika dibutuhkan, dan penanaman tanaman. Berdasarkan hasil wawancara, belum pernah ada sosialisasi pengelolaan RTH hingga saat ini. Sehingga pengelolaan taman murni hasil dari kemampuan masyarakat sekitar. Ketiadaan training/sosialisasi membuat komponen ini memiliki skor 1 berdasarkan parameter penelitian.

- Training/Sosialisasi Pengelolaan Penggunaan Energi secara Efisien

Efisiensi energi dilakukan dengan cara earth hour atau jurit malam yang dilakukan secara rutin. Sebelum adanya event earth hour atau jurit malam tersebut, dilakukan sosialisasi berupa himbauan memadamkan lampu. Himbauan tersebut bersifat rutin dan dilakukan sehari sebelum kegiatan earth hour atau jurit malam. Sosialisasi tergolong rutin dilakukan setiap sebelum kegiatan jurit malam membuat komponen ini memiliki skor 3 dilihat dari parameter penelitian.

- Training/Sosialisasi Pengelolaan Air

Pengelolaan air berwawasan lingkungan pada Kampung Cibunut adalah berupa lubang biopori yang berfungsi untuk meningkatkan daya serap air ke tanah. Edukasi dalam pengelolaan lubang biopori ini hanya diakukan di awal pembuatan lubang biopori dan hingga saat ini belum ada edukasi lebih lanjut. Ketua Komunitas OHDarling berpendapat bahwa edukasi tidak bersifat rutin karena jangka waktu dari biopori relatif lama dan dinilai hanya butuh edukasi pada awal pembuatan saja. Berdasarkan parameter penelitian, komponen ini termasuk dalam indikator tersedia training/sosialisasi namun tidak bersifat rutin, sehingga memiliki nilai skor 2.

- Training/Sosialisasi Pengelolaan Sampah

Pengelolaan sampah di Kampung Cibunut dilakukan mulai dari pemilahan sampah dari sumber, composting, daur ulang sampah, hingga bank sampah. Sosialisasi pengelolaan sampah diadakan hampir setiap sebulan sekali meski tanggalnya tidak pasti. Hal tersebut karena yang melakukan edukasi dari berbagai pihak, antara lain, GSSI, mahasiswa, dan relawan lain. Adanya sosialisasi rutin membuat pengelolaan sampah tergolong dalam indikator siap atau skor 3 . 


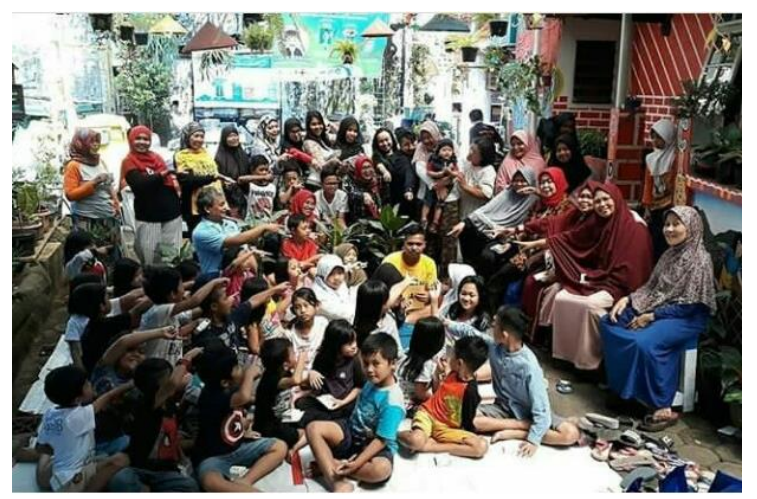

Sumber: Dokumentasi Komunitas Orang Hebat Sadar Lingkungan, 2019

Gambar 8. Sosialisasi Pengurangan Sampah kepada Anak-Anak

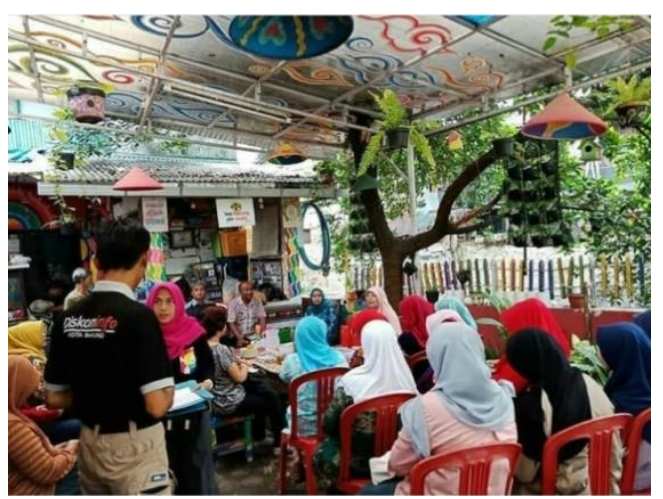

Sumber: Dokumentasi Komunitas Orang Hebat Sadar Lingkungan, 2019

Gambar 9. Sosialisasi Daur Ulang Sampah

Baik Landry maupun Kementerian PUPR, keduanya membahas mengenai kegiatan pengembangan masyarakat. Budaya berorganisasi bersifat life long learner, dimana ada upaya dalam pengembangan kemampuan kapasitas masyarakat (Landry, 2008). Pengembangan kapasitas masyarakat yang bersifat life long learner dapat dikatakan bersifat rutin. Kementerian PUPR dalam P2KH menambahkan bahwa, peningkatan partisipasi masyarakat dapat dilakukan dengan sosialisasi (KemenPUPR, 2017). Sosialisasi yang paling rutin dilakukan adalah efisiensi dan pengelolaan sampah. Sosialisasi efisiensi energi dilakukan dengan pemberitahuan 1-2 hari sebelum dilakukan kegiatan earth hour atau jurit malam. Meski sosialisasi hanya bersifat himbauan, 98\% masyarakat turut serta dalam memadamkan lampu. Sosialisasi untuk pengelolaan sampah hampir dilakukan sebulan sekali, namun tidak ada tanggal yang pasti (lihat Gambar 8 dan 9). Hal tersebut dikarenakan, pemateri datang dari berbagai pihak, mulai dari GSSI, mahasiswa, atau sukarelawan lain. Sedangkan sosialisasi lubang biopori hanya dilakukan di awal pembuatan saja, setelahnya tidak ada sosialisasi lain, karena lubang biopori dinilai memiliki jangka waktu yang panjang. Untuk komponen pemeliharaan $\mathrm{RTH}$, tidak ada sosialisasi dalam pengelolaan RTH. Pemeliharaan RTH dilakukakan murni dari inisiatif masyarakat sendiri. Dengan demikian, sosialisasi rutin berada pada efisiensi energi dan pengelolaan sampah, sehingga kedua komponen tersebut memiliki skor 3. Sedangkan, sosialisasi biopori hanya dilakukan sekali saat pembuatan, sehingga dinilai tidak rutin dan mendapatkan skor 2. Untuk pengelolaan RTH tidak ada training khusus, oleh karena itu mendapatkan skor 1 . Adanya sosialisasiltraining membuat masyarakat tidak hanya diam di satu titik dengan pengetahuan yang tidak bertambah. Menurut Landry, pengembangan kemampuan kapasitas masyarakat juga dapat memicu pemikiran kreatif untuk muncul.

Rata-rata skor untuk komponen ketersediaan kegiatan pengembangan kemampuan masyarakat adalah 2.25 atau dinterpretasikan sebagai cukup siap. Hal ini dikarenakan, meski telah ada sosialisasi rutin pada pengelolaan sampah dan efisiensi energi, namun tidak pernah ada sosialisasi untuk pengelolaan RTH. Padahal RTH merupakan salah satu komponen dari kampung berwawasan lingkungan. Selain itu, sosialisasi mengenai pengelolaan air dilakukan sekali, yakni sebelum pembuatan lubang biopori. Setelah itu belum ada sosialisasi lagi mengenai pengelolaan air.

Komponen yang kedua berkaitan dengan kepemimpinan di Kampung Cibunut. Sosok pemimpin yang berperan dalam kegiatan kampung kreatif berwawasan lingkungan adalah ketua dari Komunitas Orang Hebat Sadar Lingkungan. Berdasarkan hasil wawancara dengan Ketua Komunitas OHDarling, Ketua dari Komunitas OHDarling tersebut memiliki beberapa rencana untuk pengembangan kegiatan berwawasan lingkungan di Kampung Cibunut, yakni :

- Rencana dalam Pengelolaan RTH

Rencana pengelolaan RTH adalah melakukan penanaman tanaman di taman-taman yang tersebar di Kampung Cibunut atau disebut dengan penghijauan. Rencana ini akan dilaksanakan saat kompos dari hasil composting sampah masyarakat sudah siap panen. Sehingga tidak dibutuhkan dana tambahan untuk membeli kompos. Komponen pengelolaan RTH tergolong siap atau skor 3 dalam segi rencana karena telah memiliki rencana yang waktu pelaksanaannya telah ditentukan. 


\section{- Rencana dalam Efisiensi Energi}

Hingga saat ini belum ada rencana pasti mengenai pengembangan kegiatan efisiensi energi dari Ketua Komunitas OHDarling. Ketiadaan rencana yang jelas ini membuat komponen efisiensi energi tergolong dalam tidak siap atau skor 1.

\section{- Rencana dalam Pengelolaan Air}

Rencana dalam pengelolaan air adalah pembuatan sumur resapan. Sumur resapan ini berfungsi untuk mengumpulkan air hujan, sehingga air hujan tidak terbuang dan dapat dimanfaatkan. Rencana ini akan dikerjakan saat hasil dari lomba Proklim telah keluar dan akan berlokasi di sekitar taman RT 5. Rencana dalam pengelolaan air termasuk dalam indikator siap atau skor 3 , dimana telah tersedia rencana yang pelaksanaannya jelas.

- Rencana dalam Pengelolaan sampah/limbah

Untuk pengelolaan sampah belum ada rencana pasti, namun secara garis besar terdapat sebuah rencana diet plastik. Hal ini dilakukan untuk mereduksi jumlah sampah plastik yang terus bertambah dan sulit diurai. Pelaksanaan dari rencana diet plastik ini belum ditentukan waktu pelaksanaannya. Pengelolaan sampah/limbah memiliki rencana yang waktu pelaksanaannya belum ditentukan, sehingga komponen ini tergolong cukup siap dengan skor 2 .

Landry berpendapat, bahwa seorang pemimpin diperlukan dalam melihat apa yang ingin dituju dan bagaimana mencapai tujuan (Landry, 2008). Di Kampung Cibunut, sosok yang dianggap pemimpin dalam kegiatan kampung kreatif berwawasan lingkungan adalah ketua dari komunitas OHDarling. Komunitas Orang Hebat Sadar Lingkungan berperan dalam kegiatan earth hour, bank sampah, komposting, biodigester, pembuatan biopori, dan perawatan taman. Rencana yang sudah jelas waktu pelaksanaannya adalah rencana dalam pengelolaan RTH dan pengelolaan air. Rencana dalam pengelolaan RTH adalah kegiatan penanaman tanaman, atau disebut penghijauan, pada taman-taman di Kampung Cibunut. Kegiatan ini akan dimulai saat kompos sudah cukup dan siap panen. Sedangkan untuk pengelolaan air, terdapat rencana membuat sumur resapan. Rencana ini dilatarberlakangi karena air hujan yang terbuang langsung ke sungai dan drainase, padahal air hujan tersebut sebenarnya dapat digunakan sebagai cadangan air. Rencana pembuatan sumur resapan akan dimulai saat hasil dari lomba proklim sudah keluar. Rencana yang ingin dituju dalam komponen pengelolaan sampah adalah diet plastik, diet plastik bertujuan untuk mengurangi jumlah sampah plastik yang sulit diurai. Sedangkan pada komponen efisiensi energi, belum ada rencana pasti dalam pengembangannya. Jika dilihat berdasarkan pendapat Landry, rencana dalam pengelolaan RTH dan pengelolaan air memiliki waktu pelaksanaan yang telah ditentukan, sehingga kedua komponen tersebut memiliki skor 3. Sedangkan pengelolaan sampah/limbah memiliki rencana diet plastik, namun belum ditentukan waktu pelaksanaannya, sehingga mendapatkan skor 2 . Untuk efisiensi energi belum memiliki rencana pasti sehingga memiliki skor 1.

Skor rata-rata untuk komponen kepemimpinan adalah 2.25 atau tergolong cukup siap dalam mendukung penerapan kampung kreatif berwawasan lingkungan. Hal tersebut dikarenakan tidak semua komponen berwawasan lingkungan memiliki rencana dengan waktu pelaksanaan yang sudah ditentukan. Seperti belum adanya rencana mengenai efisiensi energi untuk ke depannya serta belum adanya waktu pasti dalam pelaksanaan diet plastik yang direncanakan oleh Komunitas OHDarling. Meski dua aspek belum memiliki rencana yang cukup jelas, namun pemimpin dari Komunitas OHDarling dinilai cukup berperan dalam hal sebagai penggerak masyarakat. Hal ini dikarenakan, pemimpin dari Komunias OHDarling sering terlibat langsung dalam kegiatan, seperti contohnya pengangkutan sampah setiap sore dan earth hour. Oleh karena itu, pemimpin juga dapat berperan dalam penggerak dan memicu masyarakat untuk berpikir lebih berani serta kreatif.

Komponen kelembagaan yang ketiga adalah kerja sama, dalam pelaksanaan kegiatan berwawasan lingkungan, Kampung Cibunut telah bekerja sama dengan beberapa pihak, yaitu:

\section{- Kerja Sama dalam Pengelolaan RTH}

Kerja sama dalam pengelolaan RTH melibatkan pemerintah yaitu Dinas Pertamanan Kota Bandung; pihak swasta dari Cat Dulux; serta sukarelawan dari Alumni SMAN 3, IKA ITB, dan Kelompok Mural. Dalam pengelolaan RTH, Dinas Pertamanan berperan dalam penyediaan tanaman-tanaman. Sedangkan kelompok mural berperan dalam pembuatan mural yang tema dan gambarnya telah disepakati oleh masyarakat. Sebelum pembuatan mural, perwakilan masyarakat, pengurus RW, pengurus RT, dan Komunitas OHDarling melakukan musyawarah guna mencapai keputusan mengenai tema dan gambar. Cat Dulux berperan dalam menyediaan cat yang kemudian digunakan untuk kegiatan mural. Pengelolaan RTH memiliki 3 kerja sama antara pihak pemerintah, swasta, dan sukarelawan. Sehingga, komponen kerja sama termasuk dalam indikator siap dengan skor 3. 
- Kerja Sama dalam Penggunaan Energi Berwawasan Lingkungan

Event jurit malam dilakukan oleh Karang Taruna, Karang Taruna sendiri merupakan panitia acara 17 Agustus setiap tahunnya. Selain itu terdapat kerja sama dengan pihak sukarelawan yaitu Jurnal Risa yang juga memiliki acara Sandekala (acara jurit malam di Jalan Sunda - Baranangsiang). Dalam acara Sandekala tersebut terdapat pula kerja sama dengan RW 9 dan RW 1. Kedua RW berperan dalam pemadaman listrik guna mendukung acara jurit malam tersebut. Kerja sama dalam penggunaan energi berwawasan lingkungan meliputi pihak dalam kawasan dan pihak sukarelawan, sehingga komponen ini tergolong cukup siap dengan skor 2.

- Kerja Sama dalam Pengelolaan Air Berwawasan Lingkungan

Pengelolaan air berwawasan lingkungan dilakukan dengan lubang biopori. Lubang biopori merupaka kerja sama antara Kampung Cibunut dengan pihak pemerintah, yaitu DLHK Kota Bandung. DLHK Kota Bandung sendiri berperan dalam penyediaan fasilitas untuk membuat lubang biopori (bor). Selain itu, terdapat pula kerja sama dengan pihak sukarelawan, yaitu GSSI yang merupakan fasilitator dari pihak DLHK Kota Bandung. Adanya kerja sama dengan pihak pemerintah dan pihak sukarelawan membuat komponen pengeloaan air tergolong cukup siap dengan skor 2.

- Kerja Sama dalam Pengelolaan Sampah/Limbah Berwawasan Lingkungan

Pengelolaan sampah/limbah dilakukan dengan kerja sama antara Kampung Cibunut dan pihak pemerintah, yakni DLHK Kota Bandung. Pada kerja sama ini, DLHK Kota Bandung berperan dalam penyediaan biodigester dan penunjukan Kampung Cibunut sebagai bagian dari Kawasan Bebas Sampah. Selain itu terdapat kerja sama dengan GSSI sebagai fasilitator dalam mengedukasi masyarakat. Terdapat pula kerja sama dengan beberapa mahasiswa yang mengambil penelitian yang berlokasi di Kampung Cibunut, kerja sama ini biasanya berupa edukasi. Komponen ini tergolong cukup siap atau skor 2, karena telah ada kerja sama dengan pihak pemerintah dan sukarelawan.

Aspek kelembagaan terakhir adalah kerja sama. Menurut Landry (2008), penciptaan lingkungan kreatif dilakukan dengan adanya jaringan kerja sama, baik dengan pemerintah, swasta, dan sukarelawan. Meskipun di Kampung Cibunut terdapat berbagai kerja sama dengan pemerintah, swasta, dan sukarelawan, namun tingkat kesiapan untuk komponen kerja sama adalah cukup siap atau rata-rata skor 2.25. Hal ini dikarenakan tidak semua kegiatan bekerja sama dengan ketiga aktor tersebut. Dalam pengelolaan taman, Kampung Cibunut bekerja sama dengan pemerintah, yaitu Dinas Pertamanan dalam penyediaan tanaman; pihak swasta, yakni cat dulux dalam penyediaan cat; dan sukarelawan dalam penyediaan dana, yaitu Alumni SMA 3, IKA ITB, dan Kelompok Mural yang membantu melakukan pembuatan mural. Sedangkan dalam kegiatan jurit malam atau efisiensi energi kerja sama dilakukan oleh pihak Karang Taruna dan juga sukarelawan dari Jurnal Risa. Untuk pengelolaan air dan juga pengelolaan sampah, kerja sama dilakukan dengan pihak pemerintah,yaitu DLHK dalam penyediaan alat pembuatan lubang biopori dan biodigester, serta pihak sukarelawan, yakni GSSI yang ditunjui sebagai fasilitator oleh DLHK. Kegiatan yang memiliki skor kerja sama tertinggi atau 3 adalah pengelolaan RTH, dimana terdapat kerja sama antara pemerintah, swasta, dan sukarelawan. Sedangkan kegiatan lainnya cenderung memiliki dua jenis kerja sama, sehingga memiliki skor 2.

Rata-rata skor untuk komponen kerja sama adalah 2.25. Adanya kerja sama dengan pihak luar membuat Kampung Cibunut lebih dikenal oleh masyarakat luas. Salah satu dampak positifnya adalah beberapa kampung yang datang karena tertarik untuk belajar pengelolaan sampah dan kegiatan-kegiatan berwawasan lingkungan lain yang berada di Kampung Cibunut. Namun, meski telah memiliki beberapa kerja sama, yang mampu memiliki kerja sama dengan ketiga pihak hanyalah pengelolaan RTH. Untuk pengelolaan air, sampah, dan efisiensi energi baru memiliki dua jenis kerja sama.

\subsection{TINGKAT KESIAPAN KAMPUNG CIBUNUT SEBAGAI KAMPUNG KREATIF BERWAWASAN LINGKUNGAN}

Tabel 5. Kesiapan Sosial Kampung Cibunut sebagai Kamung Kreatif Berwawasan Lingkungan

\begin{tabular}{|c|c|c|}
\hline Komponen & Skor & Keterangan \\
\hline Keragaman Bakat Berwawasan Lingkungan & 3 & Siap \\
\hline Kegiatan Pengembangan Masyarakat & 2.25 & Cukup Siap \\
\hline Kepemimpinan & 2.25 & Cukup Siap \\
\hline Kerja Sama & 2.25 & Cukup Siap \\
\hline Total Skor & 9.75 & \\
\hline Rata - Rata Skor & 2.44 & Cukup Siap \\
\hline
\end{tabular}


Berdasarkan hasil penjabaran setiap komponen, rata-rata skor dari kesiapan komponen sosial Kampung Cibunut dalam penerapan kampung kreatif berwawasan lingkungan adalah 2.44 (lihat Tabel 5). Dengan skor 2.44 maka dapat diinterpretasikan bahwa Kampung Cibunut dinilai cukup siap dalam penerapan kampung kreatif berwawasan lingkungan secara sosial. Komponen paling besar berada di keragaman bakat berwawasan lingkungan, hal ini dikarenakan masyarakat Kampung Cibunut mampu dalam merawat taman, melakukan efisiensi energi, pengelolaan air dengan lubang biopori, serta pengelolaan sampah dengan pemilahan sampah dari sumber, bank sampah, dan composting. Meskipun komponen keragaman bakat memiliki skor tinggi dan tergolong siap, namun komponen dari aspek kelembagaan masih dikategorikan cukup siap. Hal ini dikarenakan, ada beberapa kegiatan pengembangan bakat yang belum dilakukan secara rutin, bahkan belum pernah ada. Sedangkan dari segi kepemimpinan, meski pemimpin termasuk dalam sosok yang mampu menggerakkan masyarakat, namun ada beberapa rencana pengembangan yang belum ditentukan waktu pelaksanaannya, seperti rencana diet plastik dan rencana efisiensi energi untuk ke depannya. Di Kampung Cibunut telah memiliki berbagai kerja sama dalam hal kegiatan berwawasan lingkungan. Namun tidak semua kegiatan berwawasan lingkungan memiliki kerja sama dengan ketiga pihak; pemerintah, swasta, dan sukarelawan.

\section{KESIMPULAN}

Kesiapan kampung kreatif berwawasan lingungan dari segi sosial dapat dilihat dari keragaman bakat masyarakat yang berkenaan dengan kegiatan berwawasan lingkungan, ketersediaan kegiatan pengembangan kemampuan masyarakat yang rutin, kepemimpinan dengan tujuan yang jelas, dan adanya kerja sama dengan pihak luar, seperti pemerintah, swasta, serta sukarelawan. Di Kampung Cibunut sendiri, mayoritas masyarakat mampu dalam pengelolaan air melalui lubang biopori, efisiensi energi, merawat taman, dan pengelolaan sampah dengan pemilahan sampah dari sumber, bank sampah, serta komposting. Sedangkan untuk kegiatan pengembangan masyarakat, sosialisasi berkaitan dengan pengelolaan sampah dan efisiensi energi tergolon rutin. Pada komponen kepemimpinan, sudah terdapat rencana yang memiliki waktu pelaksanaan yang telah ditentukan, rencana tersebut meliputi pembuatan sumur resapan setelah hasil dari lomba Proklim keluar dan rencana dalam merawat tanaman atau disebut penghijauan saat pupuk kompos yang dibuat komunitas OHDarling telah jadi. Untuk kerja sama, rata-rata setiap kegiatan berwawasan lingkungan yang berada di Kampung Cibunut telah memiliki kerja sama dengan satu hingga 3 pihak luar kawasan. Dengan kondisi sosial Kampung Cibunut tersebut, maka kondisi sosial Kampung Cibunut tergolong cukup siap dalam menjadi kampung kreaif berwawasan lingkungan.

\section{DAFTAR PUSTAKA}

Archie, M. L., Clark, S., \& Braus, J. (2017). Community Engagement: Guidelines for Excellence. Washington DC: North American Association for Environmental Education.

BPS. (2017). Kecamatan Sumur dalam Angka. Bandung: BPS Kota Bandung.

Ervianto, W. I. (2016). Studi Kota Berwawasan Lingkungan di Indonesia. Konferensi Nasional Teknik Sipil 10. DOI 10.22219/jmts.v16i1.4995

Heru, A. (2015). Kampung Juara Kota Bandung. Diakses dari https://www.academia.edu/15945647/Kampung_Juara_Kota_Bandung Indrawan, R., \& Yaniawati, P. (2014). Metode Penelitian Kuantitatif, Kualitatif, dan Campuran. Bandung: PT Refika Aditama.

Landry, C. (2006). The Art of City Making. London: Earthscan.

Landry, C. (2008). The Creative City : A Toolkit for Urban Innovators. London: Eartscan.

Martini, L. (2016). Knowledge Sharing in Creative City. Procedia Computer Sharing, 79-90. https://doi.org/10.1016/j.procs.2016.09.102

Mulyadi, I. (2017). AkzoNobel Buat Lingkungan Hidup Lebih Hidup. Diakses dari https://marketing.co.id/akzonobel-buat-lingkunganlebih-hidup/

Saqina, A. (2013). Kota Bandung Akan Miliki 30 Kampung Kreatif. Diakses dari https://www.republika.co.id/berita/nasional/jawabarat-nasional/13/12/08/mxhif5-kota-bandung-akan-miliki-30-kampung-kreatif 